\section{BRS A702 CL: new early-maturing irrigated rice cultivar with herbicide tolerance}

\author{
Paulo Hideo Nakano Rangel ${ }^{1}$, Márcio Elias Ferreira ${ }^{2}$, Daniel \\ de Brito Fragoso ${ }^{1}$, Antônio Carlos Centeno Cordeiro 4 , Mabio \\ Crisley Lacerda ${ }^{1}$, Carlos Martins Santiago ${ }^{1}$, Paula Pereira Torga ${ }^{1}$, \\ Orlando Peixoto de Moraes ${ }^{1}$, José Manoel Colombari Filho ${ }^{1}$, \\ Aluana Gonçalves de Abreu ${ }^{1}$, Bernardo Mendes dos Santos ${ }^{1}$, \\ Daniel Pettersen Custódio ${ }^{1}$ and Deivison Santos ${ }^{5}$
}

\begin{abstract}
The early-maturing irrigated rice cultivar BRS A702 CL was developed by Embrapa in partnership with BASF for the Clearfield Production System of irrigated rice in the tropical region of Brazil. In the states of Tocantins and Roraima, BRS A702 CL produces a mean yield of $7,650 \mathrm{~kg} \mathrm{ha}^{-1}$.
\end{abstract}

Keywords: Oryza sativa L., grain yield, genetic improvement, clearfield production system.

\section{INTRODUCTION}

For the state of Tocantins, the irrigated rice agribusiness plays a major role in foreign exchange and employment generation (Fragoso et al. 2013). The state is the third largest rice producer in Brazil, and is estimated to produce about 619,000 tons of paddy rice on an acreage of 130,000 hectares in the 2016/2017 growing season (CONAB 2017). An irregular rainfall distribution associated with the inclusion of new cultivation areas and an intensified control by environmental agencies have restricted water extraction from rivers for crop irrigation in this state. This forces farmers to adapt their cultivation systems, in the search for more efficient ways to use water, alternatively to the conventional flood irrigation throughout the cycle.

Rice management on waterlogged soil, locally known as "várzea úmida" areas, is the best alternative to deal with limited water availability, because it has the highest environmental efficiency by reducing water use, aside from lower cultivation costs for farmers by decreasing expenses with pumping. However, in this system, weed infestation seriously limits yields (Santos et al. 2015). In addition, as rice is cultivated in the rainy season, between October and March, delays in herbicide application are common, reducing the product effectiveness. Thus, the planting of rice cultivars resistant to a broad-spectrum herbicide, e.g., Kifix $^{\circledR}$ of the chemical group of imidazolinones, which also affects red rice, is extremely important to make this cultivation system viable.

In the state of Roraima, rice agribusiness plays a vital role in the generation of employment and income and for the Gross Domestic Product (GDP), and is one of the few effectively established productive chains in the state. Most of
Crop Breeding and Applied Biotechnology 18: 446-449, 2018 Brazilian Society of Plant Breeding. Printed in Brazil http://dx.doi.org/10.1590/1984$70332018 v 18 n 4 c 66$

70332018v18n4c66 
the production ( $80 \%$ ) is exported to other states, mainly to Amazonas, and the rest (20\%) is enough to supply the state. The estimated state production in the $2016 / 2017$ growing season on a 12,000 ha area is expected to reach 86,000 tons of paddy rice (CONAB 2017). The use of herbicide-resistant rice cultivars will greatly benefit the rice farmers in this state, where part of the production occurs in "várzea úmida", which are areas prone to weed infestation (Cordeiro and Medeiros 2010).

The objective of this study was to describe the method used to breed cultivar BRS A702 CL and to describe its agronomic and morphological characteristics. This cultivar was developed by Embrapa in partnership with BASF and is recommended for cultivation using the Clearfield $(\mathrm{CL})$ Production System of irrigated rice in the states of Tocantins and Roraima. BRS A702 CL is the first short-cycle herbicide-tolerant cultivar developed especially for the tropical region of Brazil.

\section{BREEDING METHOD}

Cultivar BRS A702 CL was developed by a backcross program between commercial cultivar BRS Formoso (recurrent parent) and cultivar Cypress CL (donor parent), a tolerance source to herbicides of the chemical group of imidazolinones. Cultivar BRS A702 CL was developed with the objective of combining the good agronomic characteristics of BRS Formoso, e.g., high lodging tolerance, high yield, grains with excellent industrial and culinary qualities, and tolerance to the Kifix ${ }^{\circledR}$ broad-spectrum herbicide of the imidazolinone group. The cultivar was developed by Embrapa Rice \& Beans, in partnership with BASF, in Goianira, state of Goiás, by the methodology recommended by Rangel et al. (2018). Apart from the initial crossing, three backcrosses were performed, with individual plant selection in each generation, and the whole transfer process of the tolerance allele was performed in a greenhouse. The seeds of the segregating generations were sown in plastic trays in a greenhouse, and 20 days after plant emergence, herbicide Kifix was applied, at a rate of $180 \mathrm{~g}$ of the commercial product per hectare, along with the adjuvant Dash at a rate of $0.5 \% \mathrm{v} / \mathrm{v}$. Ten days after herbicide application, tolerant plants were identified and transplanted into pots. At flowering, separate backcrossing was performed with the recurrent parent. After progeny tests in the RC3F3 generation, eight homozygous families, carriers of the tolerance allele, were selected. These CL families were evaluated in the 2008/09 growing season for herbicide tolerance and agronomic characteristics in tests in Goianira, GO, to select the five best CL families. In the 2010/2011 and 2011/2012 growing seasons, these families, together with the controls BRS Formoso and BRS Alvorada, were evaluated in VCU (Value for Cultivation and Use) test series in Tocantins and Roraima. In view of its performance, line AB101053 CL was recommended for irrigated rice cultivation in the Clearfield system in Tocantins and Roraima and named BRS A702 CL.

\section{PERFORMANCE CHARACTERISTICS}

BRS A702 CL was evaluated in 14 VCU tests carried out in 2010/2011 and 2011/2012 in Tocantins and Roraima. The mean yield of BRS A702 CL was 7,650 kg ha-1, similar to that of the two controls, BRS Alvorada $\left(7,698 \mathrm{~kg} \mathrm{ha}^{-1}\right)$ and BRS Formoso $\left(7,293 \mathrm{~kg} \mathrm{ha}^{-1}\right)$ (Table 1$)$

The new cultivar has an early-maturing cycle with medium flowering after 80 days, 16 days earlier than its recurrent parent BRS Formoso (96 days). This characteristic is extremely useful for rice farmers who can stagger harvest dates by growing cultivars with differentiated crop cycles. In this way, the crop can be harvested at the ideal moisture content, ensuring a high-quality product on the entire field (Table 1).

Table 1. Mean grain yield (YLD), mean number of days to flowering (FLO), mean plant height (HGT) and lodging incidence (LOD) of cultivar BRS A702 CL and control cultivars (BRS Alvorada and BRS Formoso) assessed in VCU (Value for Cultivation and Use) test series in the $2010 / 2011$ and $2011 / 2012$ growing seasons

\begin{tabular}{|c|c|c|c|c|}
\hline Cultivar & YLD $^{1}\left(\mathrm{~kg} \mathrm{ha}^{-1}\right)$ & FLO (days) & HGT $(\mathrm{cm})$ & $\operatorname{LOD}^{2}(1-9)$ \\
\hline BRS A702 CL & $7,650 a b$ & 80 & $90 a b$ & 1 \\
\hline BRS Alvorada & 7,698 a & 96 a & 99 a & 1 \\
\hline BRS Formoso & $7,293 \mathrm{~b}$ & $96 \mathrm{~b}$ & $91 b$ & 1 \\
\hline Mean & 7,042 & 80 & 93 & \\
\hline CV (\%) & 9.33 & 1.48 & 3.81 & \\
\hline
\end{tabular}

${ }^{1}$ Data of 14 tests; six in 2010/2011 and eight in 2011/2012.

2 Lodging on a 1 to 9 score scale, where 1 - absence of lodging and 9 - completely lodged plants. (Pinheiro et al. 2009)

Means followed by the same letter are not significantly different at $5 \%$ probability by Dunnett (1955; 1964)'s Test. 
Table 2. Yield of whole milled grain percentage (WhG), broken grains (BG), total grains (TG), chalky grains (Ch), grain length (L), width (W), L/W ratio, grain type and stickiness (ST) of cultivar BRS A702 CL and controls (BRS Formoso and BRS Alvorada), in VCU tests in the $2010 / 2011$ and $2011 / 2012$ growing seasons

\begin{tabular}{lccccccccc}
\hline Cultivars & WhG\% & BG\% & TG\% & Ch\% & L (mm) & W (mm) & L/W & Grain type & ST $^{1}$ \\
\hline BRS A702 CL & 60.64 & 11.97 & 72.62 & 1.97 & 6.68 & 2.12 & 3.16 & long fine & Lo \\
BRS Alvorada & 66.00 & 6.95 & 72.69 & 2.42 & 6.68 & 2.15 & 3.10 & long fine & St \\
BRS Formoso & 60.28 & 12.53 & 72.82 & 2.21 & 6.66 & 2.06 & 3.23 & long fine & SLo \\
\hline
\end{tabular}

${ }^{1}$ Lo = loose grains; St = sticky grains; SLo = slightly loose grains

The plant height of cultivar BRS A702 CL was $90 \mathrm{~cm}$, statistically equal to that of the two controls, BRS Alvorada $(99 \mathrm{~cm})$ and BRS Formoso $(91 \mathrm{~cm})$, and highly tolerant to lodging, a fundamental characteristic for a product with high industrial quality (Table 1).

The industrial and culinary grain quality are key traits taken into account for the release of a rice cultivar. Cultivar BRS A702 CL has fine long grains. The milled grains are classified as fine long and have a mean length $(\mathrm{L})$ of 6.68 $\mathrm{mm}$ and width $(\mathrm{W})$ of $2.12 \mathrm{~mm}$, with a L/W ratio of 3.16 , as well as a vitreous appearance, with low grain chalkiness (only $1.97 \%$ ). Another important industrial trait is the high yield of whole milled grains (60.64\%) and total milled grains (72.62\%) (Table 2). After cooking, the grains of cultivar BRS A702 CL are loose and soft, as preferred by Brazilian consumers.
Table 3. Main descriptors of rice cultivar BRS A702 CL

\begin{tabular}{lc}
\hline Descriptor & Phenotypic expression \\
\hline Leaf color & Green \\
Flag leaf angle & Right \\
Pubescence of leaf blade & Medium \\
Leaf: auricle color & Light green \\
Leaf: ligule color & Colorless to green \\
Stem length & Medium $(72 \mathrm{~cm})$ \\
Panicle length & Medium $(22 \mathrm{~cm})$ \\
Presence of awn & Absent or very short \\
Spikelets: glume color & Straw $/$ Golden \\
Spikelets: bud color & White \\
Dehulled grain length & Long $(6.68 \mathrm{~mm})$ \\
1000 -grain weight & 27.1 to 28.5 \\
\hline
\end{tabular}

Blast (Magnaporthe oryzae) is the main yield-limiting factor for irrigated rice in the tropical region of Brazil. The diversity of $M$. oryzae pathotypes reported so far in Brazil is highest in irrigated rice areas in the Araguaia River Valley, state of Tocantins, Dias Neto et al. (2010) obtained 479 M. oryzae monosporic isolates, which belonged to 45 different races from seven out of nine pathotype groups (IA, IB, IC, ID, IE, IF, IG). This diversity could explain the rapid resistance breakdown in this region, only two years after cultivar release. With regard to rice diseases, the incidence of leaf and panicle blast, leaf scald and grain spot on BRS A702 CL was low. Even when blast incidence is low, we suggest moderate fungicide application as a complementary control strategy to ensure high yields of the cultivar.

In addition, BRS A702 CL was assessed in tests of distinctness, homogeneity and stability (DHS), required by the Ministry of Agriculture, Livestock and Supply (MAPA) to register and protect a cultivar. Some of the data of the DHS tests are listed in Table 3.

The similarity coefficient between BRS A702 CL and its recurrent parent BRS Formoso was 0.95 (Band coefficient; Lynch 1990). This estimate was based on DNA polymorphism analysis of 4,200 SNP markers, using the Illumina DNA Biochip OSBR, Embrapa, Brazil, distributed on the 12 chromosomes of the species.

BRS A702 CL has several favorable agronomic characteristics, e.g., early maturation, high lodging tolerance, high yield, grains with good industrial and culinary quality, and above all tolerance to the herbicide Kifix ${ }^{\circledR}$.

\section{SEED PRODUCTION}

BRS A $702 \mathrm{CL}$ is registered in the National Register of Cultivars (RNC, registry number No. 34461) and protected by the Ministry of Agriculture, Livestock and Food Supply (MAPA). The Business Office of Embrapa Products and Market in Goiania, in partnership with BASF, will be in charge of the production seed of the cultivar.

To obtain seed with high genetic purity, 100 plants of the cultivar were selected and sown in pots (one plant pot ${ }^{-1}$ ). Leaves were sampled for DNA extraction and the plants were harvested individually. The 100 plants were genotyped with 
4,200 SNP markers using a DNA chip (Illumina BeadChip OSBR, distributed on the 12 chromosomes of the species, to obtain DNA polymorphism data throughout the rice genome. The multilocus profile of each plant allowed an estimation of the individual genome recovery rate of the recurrent parent. The nine plants with the highest genome conversion rate $(95 \%)$ and with an identical multilocus genetic profile were selfed and the progenies evaluated in the field. Seeds of these families were sown in trays and the seedlings transplanted to the field (one seed per pit). All plants of the nine families were rigorously screened to eliminate atypical plants and the seeds were bulk-harvested for seed production.

\section{REFERENCES}

CONAB (2017) Séries históricas de produção. Safras 1996/1997 a 2016/2017. Available at <http://www.conab.gov.br>. Accessed in January 2017.

Cordeiro ACC and Medeiros RD (2010) BRS Jaçanã e BRS Tropical: cultivares de arroz irrigado para os sistemas de produção de arroz em várzea de Roraima. Revista Agro@mbiente On-line, 4: 67-73.

Dias Neto JJ, Santos GR, Anjos LM, Rangel PHN and Ferreira ME (2010) Hot spots for diversity of Magnaphorte oryzae physiological races in irrigated rice fields in Brazil. Pesquisa Agropecuária Brasileira 45: $252-260$.

Dunnet CW (1955) A multiple comparison for comparing several treatments with control. Journal of the American Statistical Association 50: 1096-1121.

Dunnet CW (1964) A new Table for multiple comparisons with control. Biometrics 20: 482-491.

Fragoso DB, Cardoso EA, Souza ER and Ferreira CM (2013) Caracterização e diagnóstico da cadeia produtiva do arroz no estado do Tocantins. Embrapa Arroz e Feijão, Santo Antônio de Goiás, 40p.

Lynch M (1990) The similarity index and DNA fingerprinting. Molecular Biology and Evolution 7: 478-484.

Pinheiro PV, Lopes Junior S, Oliveira JP, Guimarães CM, Stone LF, Madari BE, Filippi MCC, Pereira HS, Eifert EC, Silva JFA, Wendland A, Murillo Lobo Junior M and Ferreira EPB (2009) Variáveis experimentais da Embrapa Arroz e Feijão. Embrapa Arroz e Feijão, Santo Antônio de Goiás, 80p. (Documentos 250).

Rangel PHN, Magalhães Junior AM, Fagundes PRR, Morais OP, Franco D, Colombari Filho JM, Torga PP, Nunes CD, Abreu AG, Petrini JA and Ferreira ME (2018) BRS A701 CL: a new irrigated rice cultivar adapted to the clearfield production system. Crop Breeding and Applied Biotechnology 18:226-228.

Santos AB, Stone LF and Silva SC (2015) Estratégia de irrigação para a cultura do arroz na região tropical. Embrapa Arroz e Feijão, Santo Antônio de Goiás, 80p. (Documentos 250). Available at <https://ainfo. cnptia.embrapa.br/digital/bitstream/item/135791/1/CNPAF-ct231. pdf $>$. Accessed in April 2017. 